\section{Soil Heating and Secondary Plant Covers Influence Growth and Yield of Winter High Tunnel Spinach}

\author{
Dan Drost ${ }^{1}$ \\ Department of Plants, Soils, and Climate, Utah State University, 4820 Old \\ Main Hill, Logan, UT 84322-4820 \\ Taunya Ernst \\ Department of Horticulture, Arkansas State University, 1749 State Hwy 818, \\ Clarksville, AR 72830
}

\section{Brent Black \\ Department of Plants, Soils, and Climate, Utah State University, 4820 Old Main Hill, Logan, UT 84322-4820}

Additional index words. hoop house, low tunnels, protected cultivation, row covers, root zone heating, Spinacia oleracea

\begin{abstract}
High tunnel (HT) winter production may be limited by extreme low air temperatures, suboptimal soil temperatures, large diurnal temperature changes, and short daylengths and associated low light conditions. To determine the productivity of spinach in extreme climates, HT production trials were conducted in the fall (October to December) and winter (January to March) of 2010-12 at the Greenville Research Farm in Logan, UT (lat. $41 \mathrm{~N}$. elevation $1455 \mathrm{~m}$ ). Soil heating $( \pm)$ using electric cables and secondary covers (fabric rowcovers and plastic low tunnels) were evaluated to determine combined effects on fall and winter spinach production. Soil heating significantly increased yield in all cover treatments in the Fall 2010 (F2010) trial when spinach was planted in November, but had little to no effect on plant productivity in the other three trials (more appropriate planting dates) even though it did increase soil temperature marginally. The addition of secondary covers significantly increased plant biomass and leaf area when compared with the uncovered control. Excluding the F2011 trial when spinach was planted earlier under more favorable temperature and light conditions, the use of low tunnels resulted in significantly higher spinach yields (biomass and leaf area) than when grown under fabric rowcover. In the fall, relative growth rates (RGRs) decreased exponentially regardless of whether the soil was heated or not heated or if a secondary cover was used. This response was because of the seasonal decline in light levels and temperatures. In the winter production cycle, spinach relative growth without covers was similar or increased as climatic conditions improved. For plants grown under fabric or plastic rowcovers, RGR remained more constant or decreased during the production cycle. Increased yields were possible with secondary covers as air temperatures increase more quickly in the morning, maintained optimal temperatures longer each day (higher growing degree hours), and retained trapped heat later into the evening. Statistical interaction between heating cables and secondary covers were rarely observed. Fall and winter HT spinach production increases when further protection with secondary plant covers is provided; however, supplemental soil heating is not necessary.
\end{abstract}

The use of HT has successfully extended production time (early- and late-season) of several high value crops (Hunter et al., 2012;

\footnotetext{
Received for publication 22 May 2017. Accepted for publication 25 July 2017.

Funding was provided by grants from the Utah Department of Agriculture and Food-Specialty Crop Block Grant program (UTG091028-030) with additional funding from the Utah Agricultural Experiment Station-Utah State University (journal paper number 8992).

We gratefully acknowledge the technical assistance of James Frisby. Use of trade names does not imply an endorsement of the products named or criticism of similar ones not named.

${ }^{1}$ Corresponding author. E-mail: dan.drost@usu. edu.
}

Rader and Karlsson, 2006; Rowley et al., 2010; Waterer, 2003) in cold or high elevation climates. By passively trapping heat under plastic covers, HT air temperatures can be 10 to $30^{\circ} \mathrm{C}$ higher than ambient air temperatures during the day (Wien et al., 2006) and 3 to $5{ }^{\circ} \mathrm{C}$ higher at night (Wien et al., 2006). HTs expose plants to conditions closer to their optimal temperature range for longer period each day, thereby improving growth rates and reducing low temperaturerelated stresses. However, during the winter, cold air and soil temperatures as well as seasonal changes in light levels become the main limiting factors affecting crop performance in HT.

Plant growth has a predictable response to air temperature. The minimum or base air temperature for spinach growth is 2 to $4{ }^{\circ} \mathrm{C}$ (Boswell, 1934; Koike et al., 2011; Maynard and Hochmuth, 2007), although some report values as cold as $0{ }^{\circ} \mathrm{C}$ (Marques, 2016). Spinach leaves can withstand temperatures much lower than this, when acclimated, but no growth occurs at very low temperatures (Fennell and Li, 1987). Whereas unacclimated spinach plants are cold tolerant, acclimated plants show decreased susceptibility to both cold and light damage (Ruelland et al., 2009; Schöner and Krause, 1990). Acclimated spinach plants are capable of surviving air temperatures as low as $-17{ }^{\circ} \mathrm{C}$ (Schöner and Krause, 1990), although low temperatures significantly lower photosynthesis rates. At air temperatures below the base temperature for spinach growth, decreased leaf initiation and expansion rates lower final yields. As temperatures rise above the minimum, growth rates accelerate. Maximum growth rates for spinach occur between 15 and $23^{\circ} \mathrm{C}$, the recorded optimal air temperature range (Iwama et al., 1954; Koike et al., 2011; Maynard and Hochmuth, 2007). When exposed to temperatures above the optimum, growth progressively slows down, the risk of bolting increases, and at the maximum growth temperature $\left(24\right.$ to $29{ }^{\circ} \mathrm{C}$ ), growth ceases (Koike et al., 2011; Marques, 2016; Maynard and Hochmuth, 2007). If air temperatures rise further, spinach plants could experience damage or death (Leone et al., 2003).

Root zone temperatures also affect spinach growth. Like air temperature, soil temperatures inside a HT are higher than soils outside during the winter months. However, soil temperatures within a HT during fall or winter months are often below optimal ranges, particularly at night and on cloudy days (Bumgarner et al., 2011; Hunter, 2010). Although soils have the thermal mass to store heat, once soils become cold, they require significant energy inputs to warm them, particularly if they are moist. Recorded optimal soil temperatures for spinach seed germination, root growth, and functionality are between 7 and $23{ }^{\circ} \mathrm{C}$ (Maynard and Hochmuth, 2007). Root zone temperatures above or below this alter normal root growth and affect the plants' ability to uptake water and nutrients from the soil (Bumgarner et al., 2012).

In addition to low temperatures, HT experience large diurnal temperature fluctuations which are quite common in the western United States (www.climate.usu.edu). Within a HT, day-to-night temperatures can fluctuate by $40{ }^{\circ} \mathrm{C}$ or more. While spinach is cold hardy and frost tolerant, the effect of extreme diurnal temperature fluctuations on plant production is unknown. Growth could be stunted, and irreversible damage to plant tissues and important physiological processes could occur, resulting in diminished yields Cloud cover and associated weather conditions (rain/snow) can influence these fluctuations. As autumn transitions into winter and then to spring, there is an increase in cloudy or snowy conditions in the mountain regions 
of the western United States (www.climate.usu. edu). These events are variable but may have a significant influence on potential crop productivity in fall or winter production periods.

The use of secondary covers (low tunnels and floating rowcovers) within HTs can increase temperatures around plants beyond that of the HT alone. When secondary covers are used in conjunction with a HT, plants with extra protection may spend a longer period each day at temperatures near or within their optimal range (Bumgarner et al., 2011, 2012; Hunter et al., 2012; Wien et al., 2006). Additional layer of plastic or fabric can increase air temperature adjacent to plants by 5 to $10{ }^{\circ} \mathrm{C}$ on sunny days and 3 to $5{ }^{\circ} \mathrm{C}$ at night (Lamont, 2009; Waterer, 2003; Wells and Loy, 1985; Wien et al., 2006). Borrelli et al. (2013) noted the need to better regulate extreme temperature fluctuations and to maintain consistent growing conditions for crops throughout the winter. They suggested that low tunnels or rowcovers be used inside HT to enhance crop growth when additional heat or insulation is necessary. Thus, the combination of HT and secondary covers not only successfully increases biomass and yields of a range of vegetables (Bumgarner et al., 2011; Hunter et al., 2012), but also exposes plants to temperatures closer to their maximum which may be harmful to productivity.

The addition of soil heating cables generally leads to an increase in the total yield for early spring grown tomatoes, bush beans, peppers, broccoli, and lettuce (Bumgarner et al., 2011; Hunter et al., 2012; Rykbost et al., 1975) and results in increased yield for winter-grown lettuce (Bumgarner et al., 2011, 2012; Hunter, 2010). Additional heat increased total plant biomass and nutrient uptake by maintaining root zone temperatures above freezing and closer to optimal root temperature. Spinach with its greater cold tolerance should see similar increases in production levels during late fall and early winter production periods when provided with supplemental heat.

The objective was to evaluate the use of secondary covers in concert with heating to provide additional protection during HT fall and winter production periods.

\section{Materials and Methods}

Experiments were conducted in two or three identical (replicate) HTs $(12.8 \mathrm{~m}$ by $4.3 \mathrm{~m}$ ), oriented east-west, on the Utah Agricultural Experiment Station Greenville Research Farm in North Logan, UT (lat. $41.77^{\circ} \mathrm{N}$, long. $111.81^{\circ} \mathrm{W}, 1382 \mathrm{~m}$ elevation, 135 frost free days). The studies were conducted in the fall (October to December) of 2010 and 2011 and the winter (January to March) of 2011 and 2012.

\section{Site preparation}

Each HT received a preplant fertilizer application of $11.2 \mathrm{~g}$ of nitrogen per $\mathrm{m}^{2}$ in the form of ammonium sulfate which was incorporated $15-20 \mathrm{~cm}$ into the soil with a hand-operated rototiller. Soil tests conducted for each fall indicated that phosphorus or potassium were adequate for spinach and hence were not added. HTs were divided into $18,1.5 \mathrm{~m}$ long (orientation $\mathrm{N}-\mathrm{S}$ ) $\times 0.9 \mathrm{~m}$ wide $(\mathrm{E}-\mathrm{W})$ plots with $0.3 \mathrm{~m}$ between plots and with a $0.6 \mathrm{~m}$ center aisle. Each HT contained three blocks of six treatments consisting of main effect of soil heating $( \pm)$ and subplots with secondary covers (uncovered control, floating rowcover, or plastic low tunnels). Soil heating treatments were randomly assigned within blocks and cover treatments randomly assigned within heating treatments.

\section{Supplemental heating}

Heavy duty soil heating cables (Wrap-On Company Inc., Bedford Park, IL) were installed as directed by the manufacturer. Cables were buried $\approx 2-3 \mathrm{~cm}$ below the soil surface and were spaced $30 \mathrm{~cm}$ apart. Each cable was attached to a Model 18500 heater controlled thermostat (Wrap-On Company Inc.) with a remote soil sensor. Cables were activated when the soil temperature dropped below $15{ }^{\circ} \mathrm{C}$. Heating cables $( \pm)$ constituted the main effect in these studies.

\section{Transplant production}

The spinach cultivar 'Space' (Johnny's Selected Seeds, Winslow, ME) was used in all experiments. Seeds were planted in 128cell flats on 4 Oct. and 20 Dec. 2010 and on 6 Sept. and 15 Dec. 2011. Plants were grown at $20{ }^{\circ} \mathrm{C}$ day and $15{ }^{\circ} \mathrm{C}$ night, in a heated greenhouse for 5 weeks before transplanting into the HT. The transplants were grown in soilless mix (equal parts peatmoss, vermiculite, and perlite), watered daily, fertilized once or twice a week with soluble liquid fertilizer (20-10-20; J.R. Peters, Allentown, PA) to provide $100 \mathrm{ppm}$ of $\mathrm{N}$, and the transplants were not conditioned to cold before planting.

\section{Planting dates}

Spinach seedlings were transplanted into three identical HT (replicates) on 1, 8, and 10 Nov. 2010 (F2010), and again on 19, 21, and 24 Jan. 2011 (W2011). The trial was repeated in 2011-12 when two HT were transplanted on 11 and 14 Oct. 2011 (F2011) and on 26 and 29 Jan. 2012 (W2012). Different planting dates for the different HT helped space out workloads associated with setup, planting, and later harvest. Plant rows were spaced $15 \mathrm{~cm}$ apart (E-W orientation) with in-row plant spacing of $12 \mathrm{~cm}$ (91 plants per plot) in all trials. Plant rows were oriented so that the rows paralleled the heating cables and the transplants' root balls were planted $\approx 7-8 \mathrm{~cm}$ from the buried cables. The plants were watered immediately after planting using drip tape with $10 \mathrm{~cm}$ in-line emitter spacing with lines spaced $30 \mathrm{~cm}$ apart. Plants were watered infrequently as water use within the HT as well as low temperatures kept soils moist.

\section{Rowcovers}

Secondary covers (floating rowcover or plastic low tunnels) were installed immediately after planting. A $1.5 \times 4.3-\mathrm{m}$ section of light weight Agribon fabric rowcover (AG-19; 15 g. $\mathrm{m}^{-2}$; Agribon J\&M Industries Inc., Ponchatoula, LA) was folded into half, loosely laid over selected plots and secured in place by weed fabric staples. Fabric covered plants were not ventilated in these studies and new fabric was used for each experiment.

For the low tunnels, supports were constructed out of $1.3-\mathrm{cm}$ diameter metal electrical conduit. The tubing was bent to make a $0.3 \mathrm{~m}$ tall $\times 0.9 \mathrm{~m}$ wide arch. Arches were placed at each end of the plots and secured in place by sliding the conduit over a $0.6-\mathrm{m}$ long section of rebar inserted $0.4 \mathrm{~m}$ into the soil. The low tunnels were covered with new, clear construction-grade plastic stretched over the conduit arches, secured to the soil with weed fabric staples, and covered all transplants. In the early fall and late winter, low tunnels were ventilated to dissipate trapped heat when temperatures rose above the maximum temperature for growth.

\section{Plant growth and yield}

Each plot consisted of 13 rows of plants, with six harvest rows (different harvest dates) used for data collection with alternating, adjacent row as guard rows. Harvest dates were randomly assigned within each treatment to account for potential HT edge effects (colder near the outer wall than near the center aisle). Each harvest row consisted of seven plants and the five central plants were for data collection. Harvests were staggered and began $10 \mathrm{~d}$ after each transplanting date and continued at $10-d$ intervals. Plants were cut at the soil surface, weighed fresh, the number of leaves counted, and the leaf area determined using a LI-3100 Leaf Area Meter (LI-COR Inc., Lincoln, NE). Twenty randomly selected transplants were measured at the start of each planting to provide baseline growth measurements. Fresh weight data were used to calculate RGRs using the approach of Hoffmann and Poorter (2002).

\section{Environmental data}

Soil and air temperatures inside the HT and under the secondary covers (two reps per treatment per HT) were monitored with Type-T thermocouples (Omega Engineering, Inc., Stamford, CT) connected to an AM 16/ 32 multiplexer linked to a CR 1000 data logger (Campbell Scientific, Logan, UT). Air temperatures were measured at $7-8 \mathrm{~cm}$ above the soil surface in the rowcover treatments and soil temperatures were recorded $2.5 \mathrm{~cm}$ (about) below the surface in one of the middle rows (probe positioned $7-8 \mathrm{~cm}$ from the heating cable). HTs air temperature was measured at $1.5 \mathrm{~m}$ whereas outside air temperatures were monitored at the on-farm weather station $\approx 300 \mathrm{~m}$ away. The data logger was programmed to read air and soil temperature every $30 \mathrm{~s}$. Low, high, and average air and soil temperatures were recorded hourly. Air temperature data collected at plant height were used to calculate growing degree-hours based on the ASYMCUR heat 
unit model (Anderson et al., 1986; Black et al., 2008) modified for spinach using a base temperature of $2{ }^{\circ} \mathrm{C}$, optimum of $21{ }^{\circ} \mathrm{C}$, and a maximum of $29^{\circ} \mathrm{C}$ (Koike, et al., 2011; Maynard and Hochmuth, 2007).

Data analysis. The experimental design was a randomized complete block with HT as replications with three additional blocks within a HT. Within each HT, soil heating cables $( \pm)$ were whole plot factor and secondary rowcovers (open control, rowcover, and low tunnel) were subplot. Analysis of variance (SAS, version 9.1; SAS, Cary, NC) was used to identify differences between heating and secondary covers for two fall and winter trials. Because of differences in seasonal environmental conditions and planting dates, we did not analyze the effects of two fall or winter trials or compare fall with winter production. Orthogonal contrasts were used to determine specific treatment mean differences by further partitioning treatment sum of squares according to planned comparisons. Of particular interest was 1) the effectiveness of secondary covers (test: open control vs. covers) and 2) differences between type of rowcover (test: rowcover vs. low tunnel).

\section{Results}

Climate conditions. Climatic conditions were different for F2010 and F2011 trials. During F2010, the average daily high and low temperatures were 0.7 and $-6.7^{\circ} \mathrm{C}$, respectively, during the 60-d HT production period, whereas in F2011, average daily high and low temperatures were 5.7 and $-3.9^{\circ} \mathrm{C}$, respectively. A closer evaluation of the 10 -d production periods in the 60 -d production cycle illustrates the relative variability in air temperature differences between the 2 years (Table 1). In both fall production periods, air temperatures were higher at the start of the study, whereas midseason temperatures were low and generally stayed that way for the remainder of the season. These periodic temperature values illustrate the need to carefully identify appropriate planting dates and suggest that temperature modification approaches may be required. Experiment start date differences between the F2010 and F2011 were partially responsible for the differences in average temperature differences. Seasonal differences in light levels because of cloud cover or precipitation (rain/ snow) between years can be expected as well. Therefore, no attempt was made to directly compare growing seasons. The values provided are illustrative of the difficulties that may be experienced when attempting to produce crops in HT during marginal growing periods often encountered late in the year (October to December).

A greater number of snow days and associated cloudy conditions as well as planting date differences contributed to large differences in accumulated light levels. There were $21 \mathrm{~d}$ with snow (691 mm depth) in the F2010 and $143 \mathrm{MJ} \cdot \mathrm{m}^{-2}$ of solar energy was recorded during the $60-\mathrm{d}$ production cycle (Table 1). In F2011, there were $8 \mathrm{~d}$ of snow (265 mm depth) and $263 \mathrm{MJ} \cdot \mathrm{m}^{-2}$ of solar radiation was recorded. Light levels decreased from mid-October to late December as seasonal daylengths decreased (Table 1).

Snow days, light levels, and average high and low temperatures for the W2011 and W2012 were more similar. During W2011 trial (19 Jan. to 20 Mar.), there were $15 \mathrm{~d}$ with snow (957 $\mathrm{mm}$ depth), with average daily high and low temperatures of 4.3 and $-4.6^{\circ} \mathrm{C}$, respectively. In W2012 (27 Jan. to 28 Mar.), there were $11 \mathrm{~d}$ of snow (593 mm depth) with average high and low temperatures of 6.9 and $-2.4{ }^{\circ} \mathrm{C}$, respectively, during the 60 -d production period. Light levels in W2011 were $386 \mathrm{MJ} \cdot \mathrm{m}^{-2}$ of total solar energy while in W2012 tunnels received $494 \mathrm{MJ} \cdot \mathrm{m}^{-2}$ during the production period (Table 1). Light levels increased from late January to late March as seasonal daylengths increased. Variation in total solar radiation within a year or between the 2 years can be attributed to variations in overcast and rain-snow conditions during any 10 -d monitoring period or between the W2011 and W2012 seasons. In both years, temperatures were lower at the start of the experiment and air temperature increased as daylength and light levels increased. Although we did not statistically compare the two seasons, air temperatures outside and inside the HT were lower in W2011 than in W2012.

Soil response to soil heating and row covers. Because there were no significant interactions between soil heating and secondary covers on soil temperatures in any trials, only the main effects of heating and covers will be addressed. Heating cables were programmed to heat the soil when the soil temperature dropped below $15^{\circ} \mathrm{C}$. In the unheated control plots, soil temperature stayed below $15{ }^{\circ} \mathrm{C}$ during the day and at night often fell below $0{ }^{\circ} \mathrm{C}$ (Fig. 1A). Depending on outside environmental conditions (clear, cloudy, snow), on days when it was cloudy (22 Nov.), soil temperature in the unheated control varied by 3 to $4{ }^{\circ} \mathrm{C}$ between day and night. However, on clear, calm, and cold days (25 Nov.), day/night soil temperatures often fluctuated by 8 to $9{ }^{\circ} \mathrm{C}$.

The addition of soil heating cables resulted in soil temperatures that were 5 to $6{ }^{\circ} \mathrm{C}$ above the soil temperatures of the unheated controls (Fig. 1A). During the day, soil temperatures in the heated treatments were above the minimum soil temperature required for spinach root growth $\left(7^{\circ} \mathrm{C}\right)$, but did not regularly reach the target soil temperature of $15^{\circ} \mathrm{C}$. Whereas soil temperatures at night were reduced, heating cables were able to maintain soil temperatures significantly above those of the unheated

Table 1. Average daily net radiation $\left(\mathrm{MJ} \cdot \mathrm{m}^{-2}\right.$ ) and average air temperature inside (In) and outside (Out) the high tunnels (HTs) during six consecutive 10-d time periods in two fall $(2010$ and 2011$)$ and winter $(2011,2012)$ production periods. Net radiation levels were collected outside the HTs. The net radiation and temperature data shown are for the last planting date for each experiment.

\begin{tabular}{|c|c|c|c|c|c|c|c|c|c|}
\hline & \multirow{2}{*}{ Planting date } & \multicolumn{7}{|c|}{ Days after planting } & \\
\hline & & 10 & 20 & 30 & 40 & 50 & 60 & Sum & \\
\hline Fall 2010 & 1 Nov. & 3.48 & 1.62 & 2.39 & 2.46 & 2.07 & 2.31 & 14.33 & \\
\hline Winter 2011 & 19 Jan. & 4.13 & 5.26 & 6.64 & 2.99 & 9.66 & 9.96 & 38.64 & \\
\hline \multirow[t]{2}{*}{ Winter 2012} & 26 Jan. & 6.29 & 5.52 & 6.40 & 7.21 & 11.39 & 12.65 & 49.46 & \\
\hline & Sensor location & \multicolumn{8}{|c|}{ Avg air temp $\left({ }^{\circ} \mathrm{C}\right)$} \\
\hline \multirow[t]{3}{*}{ Fall 2011} & In & 9.69 & 6.08 & 0.82 & 0.86 & -0.34 & -6.38 & & \\
\hline & Out & 1.80 & -2.18 & -4.94 & -4.99 & -3.66 & -10.19 & & \\
\hline & & 29 Jan.* & 6 Feb. & 16 Feb. & $26 \mathrm{Feb}$. & 7 Mar. & 17 Mar. & 27 Mar. & \\
\hline Winter 2011 & In & -1.45 & -4.10 & 0.50 & -3.24 & 1.40 & 4.84 & & \\
\hline
\end{tabular}

Ten-day periods based on last planting date (see materials and methods) two fall and winter production cycles. Value represents an average temperature for the 10-d period. 

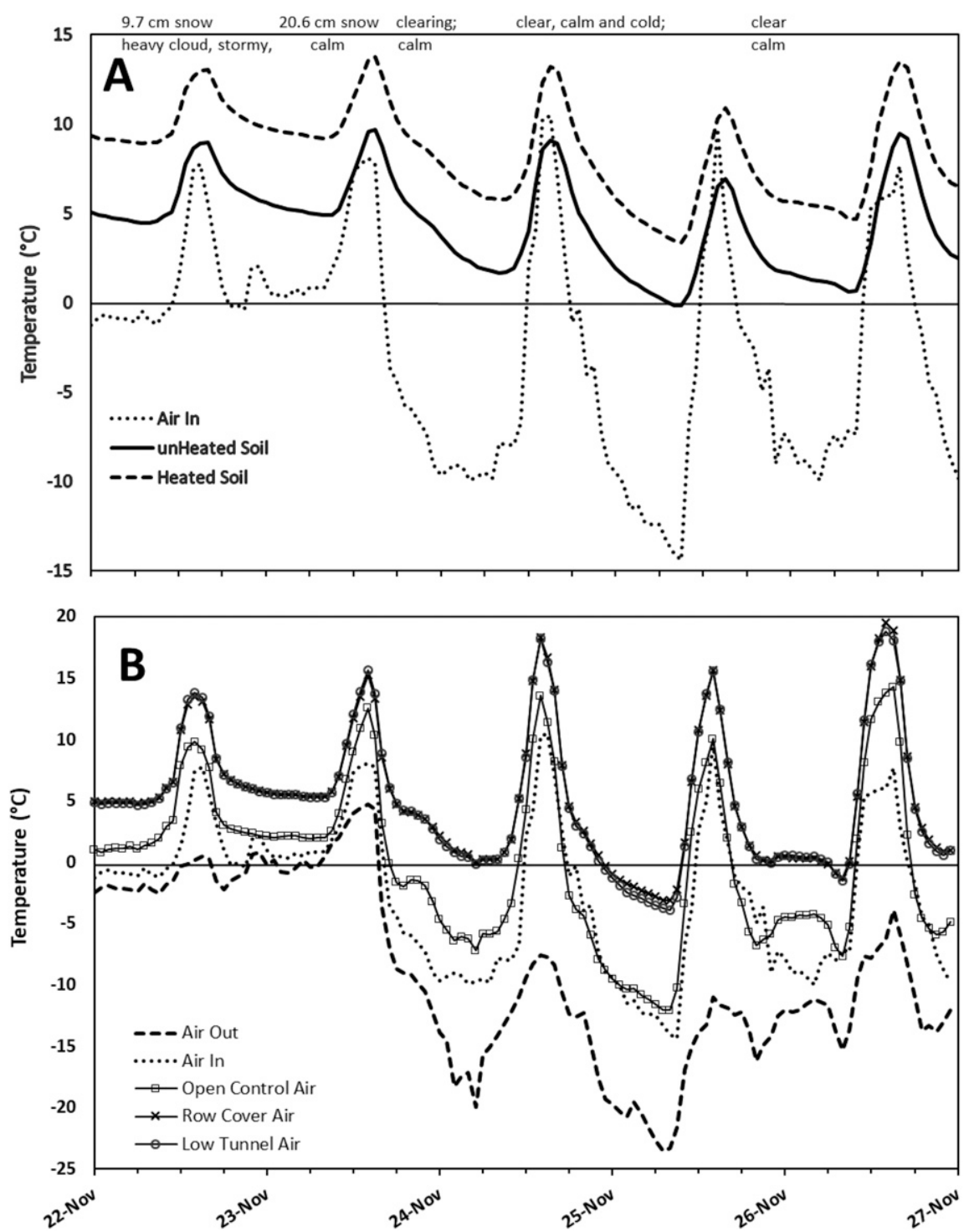

Fig. 1. Mean hourly temperatures $\left({ }^{\circ} \mathrm{C}\right)$ over $5 \mathrm{~d}(22$ to 26 Nov. 2010) inside and outside a high tunnel for (A) soil and (B) air. Soil temperatures (Panel A) were the average of supplemental heating treatments and indicate unheated (-) and heated (-) soil temperatures measured at $2.5 \mathrm{~cm}$ depth. The dashed/ dotted lines in Panels $\mathbf{A}$ and $\mathbf{B}$ indicate air temperatures measured $1.5 \mathrm{~m}$ aboveground level either outside (out - - -) or inside (in ...) high tunnels whereas solid lines with symbols in Panel B indicates air temperatures at plant level ( $7 \mathrm{~cm}$ aboveground) for open control $(\square)$, rowcover $(\times)$, and low tunnel (O). Daily environmental conditions are noted at the top of Panel A to provide reference to local conditions as provided by the Utah Climate Center (http://climate.usu.edu).

controls, and temperatures never fell below $0{ }^{\circ} \mathrm{C}$ (Fig. 1A). The impact of heating on soil temperature was more dramatic in the colder F2010 than in F2011 when spinach was planted later in the year.

Higher temperatures and increasing light levels associated with winter planting reduced the effect of heating cables on soil temperatures in W2011 and W2012. In W2012, seasonal average soil temperatures were $8.0{ }^{\circ} \mathrm{C}$ in the unheated control and $9.2{ }^{\circ} \mathrm{C}$ under the fabric rowcover and low tunnel, respectively. The average W2012 soil temperatures during the $60-\mathrm{d}$ trial in the heated treatments were 11.1, 13.3, and $15.0{ }^{\circ} \mathrm{C}$, respectively, for the uncovered control, fabric rowcover, and low tunnel. This pattern was consistent for both W2011 and W2012 and illustrates that generally, soil temperatures are high enough to support plant growth.

Soil heating had a variable and inconsistent effect on growing degree hours (GDH) accumulation (Table 2). In F2010, during all sampling dates, GDH accumulation was greater when soils were heated compared with not heated. Differences were only significant early in F2010 and when GDHs were summed over the whole experiment. In F2011, when the planting date was earlier, soil heating had little effect on GDH in heated soil, even though there were significant differences in soil temperature between heated and unheated soil (data not shown). During W2011, five of the six sampling periods recorded significant increases in GDH when soils were heated compared with not heated. In W2012, GDH increased in the heated treatments relative to the not heated, although differences between treatments were not significant (Table 2).

Air temperature responses to soil heating and plant covers. HTs alone are capable of increasing air temperatures by 10 to $25{ }^{\circ} \mathrm{C}$ during the day and maintaining air temperatures 5 to $10{ }^{\circ} \mathrm{C}$ higher than outside temperatures at night. The extent to which the HT was able to raise the air temperatures was dependent on radiant energy inputs, cloud cover, and snow events. Figure 1B shows the difference between outside ambient air temperatures, air temperatures in the HT, and temperatures recorded under the secondary covers in late F2010 (22 to 26 Nov.). On 22 Nov., climatic conditions were overcast, stormy, and $9.7 \mathrm{~cm}$ of snow fell in that $24-\mathrm{h}$ period. The HT received $520 \mathrm{~J} \cdot \mathrm{m}^{-2} \cdot \mathrm{d}^{-1}$ of solar radiation, with an outside high temperature of $0.5^{\circ} \mathrm{C}$, whereas within the HT it was $7^{\circ} \mathrm{C}$ higher. The following day ( 23 Nov.) was calm but had significant snow fall $(20.6 \mathrm{~cm})$, less solar radiation $\left(450 \mathrm{~J} \cdot \mathrm{m}^{-2} \cdot \mathrm{d}^{-1}\right)$, and slightly higher outside air temperature $\left(4.7^{\circ} \mathrm{C}\right)$, but these conditions only increased tunnel air temperature to $8.1{ }^{\circ} \mathrm{C}$ (Fig. 1B). Overnight (24 Nov.), condition cleared and outside air temperatures fell to $-20.1{ }^{\circ} \mathrm{C}$ while inside the HT, the temperature fell to $-9.9{ }^{\circ} \mathrm{C}$. During the day, outside air temperature remained very low, increasing to $-7.5^{\circ} \mathrm{C}$. Inside the HT, the high air temperature for the day reached $10.3^{\circ} \mathrm{C}$ and $666 \mathrm{~J} \cdot \mathrm{m}^{-2} \cdot \mathrm{d}^{-1}$ of radiation accumulated. Regardless of outside environmental conditions, air temperature in the HT was always higher than the outside air temperature. These patterns were consistent and representative of conditions noted in all experiments.

The use of secondary covers further intensified HT temperature differences. Air temperatures under rowcovers and low tunnels did not differ from each other and were always 3 to $5^{\circ} \mathrm{C}$ higher at night than the air temperature in HT with no additional covering (Fig. 1B). After sunrise, air temperatures increased more rapidly beneath the secondary covers than within the HT alone. On overcast, or snow days (less solar radiation), air temperatures under the low tunnels and fabric rowcovers were 10 to $15{ }^{\circ} \mathrm{C}$ higher than the outside air, and 3 to $5^{\circ} \mathrm{C}$ higher than air in the HT or air temperature at plant level in the uncovered controls. As temperatures outside the HT decreased in the late afternoon, temperatures under both secondary covers stayed above the minimum growing temperature for spinach $\left(2{ }^{\circ} \mathrm{C}\right)$ longer into the evening than in the uncovered HT plots. After sunset, and when conditions were cold and clear, both secondary covers retained more heat at night. Although night air temperatures during fall and winter production periods within the HT often dropped below freezing, secondary covers were able to maintain air temperatures above freezing on all but the coldest days (Fig. 1B, 25 Nov.). In short, air temperatures under a secondary cover were nearer the optimal growing temperatures earlier in the day, reached higher temperatures, 
Table 2. Influence of soil heating (main effect) and rowcovers (subplots) on accumulated growing degree hours (GDH) for each 10-d harvest period during fall (2010 and 2011) and winter (2011 and 2012). Values represent accumulated GDH for the final harvest date in each study because tunnel planting dates varied each year. GDH calculated with a minimum, optimum, and maximum temperature of 2,21 , and $29^{\circ} \mathrm{C}$, respectively.

\begin{tabular}{|c|c|c|c|c|c|c|c|c|c|c|c|c|c|c|}
\hline & \multicolumn{7}{|c|}{ Fall 2010 for harvest dates ending } & \multicolumn{7}{|c|}{ Winter 2011 for harvest dates ending } \\
\hline & 10 Nov. & 20 Nov. & 30 Nov. & 10 Dec. & 20 Dec. & 30 Dec. & Sum & 29 Jan. & 8 Feb. & 18 Feb. & 28 Feb. & 10 Mar. & 20 Mar. & Sum \\
\hline & \multicolumn{7}{|c|}{$\mathrm{GDH}\left(2,21,29^{\circ} \mathrm{C}\right)$} & \multicolumn{7}{|c|}{$\mathrm{GDH}\left(2,21,29^{\circ} \mathrm{C}\right)$} \\
\hline No heat & 47.46 & 19.65 & 25.87 & 33.88 & 25.55 & 17.56 & 169.98 & 42.04 & 39.46 & 51.26 & 52.59 & 61.37 & 73.23 & 319.95 \\
\hline Soil heat & 71.91 & 29.88 & 42.61 & 45.21 & 43.51 & 24.68 & 257.35 & 61.36 & 57.09 & 67.20 & 73.27 & 83.92 & 92.91 & 435.74 \\
\hline Sign 0.05 & NS & $*$ & NS & NS & NS & NS & $*$ & $*$ & $*$ & $*$ & NS & $* *$ & $* *$ & $* *$ \\
\hline Open control & 41.82 & 15.20 & 21.32 & 32.32 & 23.94 & 18.28 & 155.88 & 37.60 & 34.13 & 46.63 & 44.38 & 56.98 & 65.10 & 284.82 \\
\hline Row cover & 68.22 & 28.68 & 35.58 & 40.37 & 38.48 & 23.42 & 234.45 & 59.46 & 54.58 & 66.27 & 69.74 & 78.66 & 88.56 & 417.27 \\
\hline Low tunnel & 69.01 & 30.41 & 42.45 & 45.95 & 41.17 & 21.67 & 250.66 & 58.04 & 56.12 & 64.79 & 74.66 & 82.30 & 95.54 & 431.45 \\
\hline Covers & $* *$ & $* *$ & $* *$ & $* *$ & $* *$ & NS & $* *$ & $* *$ & $* *$ & $* *$ & $* *$ & $* *$ & $* *$ & $* *$ \\
\hline Open vs. Cover & $* *$ & $* *$ & $* *$ & $* *$ & $* *$ & NS & $* *$ & $* *$ & $* *$ & $* *$ & ** & $* *$ & $* *$ & $* *$ \\
\hline Row vs. Low & NS & NS & $*$ & NS & NS & NS & NS & NS & NS & NS & NS & NS & NS & NS \\
\hline \multirow[t]{4}{*}{ Heat $\times$ Covers } & NS & NS & NS & NS & $*$ & NS & NS & NS & NS & NS & $*$ & NS & NS & NS \\
\hline & \multicolumn{7}{|c|}{ Fall 2011 for harvest dates ending } & \multicolumn{7}{|c|}{ Winter 2012 for harvest dates ending } \\
\hline & 21 Oct. & 31 Oct. & 10 Nov. & 20 Nov. & 30 Nov. & $10 \mathrm{Dec}$. & Sum & 6 Feb. & 16 Feb. & 26 Feb. & 7 Mar. & 17 Mar. & 27 Mar. & Sum \\
\hline & \multicolumn{7}{|c|}{$\mathrm{GDH}\left(2,21,29^{\circ} \mathrm{C}\right)$} & \multicolumn{7}{|c|}{$\mathrm{GDH}\left(2,21,29^{\circ} \mathrm{C}\right)$} \\
\hline No heat & 69.74 & 86.69 & 71.83 & 49.14 & 43.38 & 37.32 & 308.74 & 51.12 & 56.34 & 62.51 & 54.10 & 86.34 & 109.73 & 420.13 \\
\hline \multirow[t]{2}{*}{ Soil heat } & 73.32 & 88.83 & 75.19 & 51.69 & 45.81 & 39.82 & 323.63 & 56.70 & 64.70 & 69.87 & 59.99 & 91.27 & 115.74 & 453.40 \\
\hline & NS & NS & NS & NS & NS & NS & NS & NS & NS & NS & NS & NS & NS & NS \\
\hline Open control & 63.25 & 75.08 & 65.57 & 43.53 & 39.80 & 35.31 & 282.26 & 50.32 & 57.98 & 62.22 & 57.14 & 88.97 & 110.74 & 430.36 \\
\hline Row cover & 74.59 & 91.46 & 77.47 & 53.75 & 46.96 & 41.22 & 332.88 & 55.30 & 62.49 & 68.54 & 55.91 & 90.05 & 115.95 & 447.42 \\
\hline Low tunnel & 76.75 & 95.84 & 77.49 & 53.97 & 47.03 & 39.25 & 333.42 & 59.47 & 64.10 & 67.46 & 58.09 & 87.39 & 111.51 & 449.52 \\
\hline Covers & $*$ & $* *$ & NS & $* *$ & $* *$ & NS & $* *$ & $*$ & * & * & NS & NS & NS & NS \\
\hline Open vs. Cover & $* *$ & $* *$ & NS & $* *$ & $* *$ & NS & $* *$ & $* *$ & $*$ & $*$ & NS & NS & NS & NS \\
\hline Row vs. Low & NS & NS & NS & NS & NS & NS & NS & NS & NS & NS & NS & NS & NS & NS \\
\hline Heat $\times$ Covers & NS & $*$ & NS & $*$ & NS & NS & $*$ & NS & NS & NS & NS & NS & NS & NS \\
\hline
\end{tabular}

Not significant (NS) or significant at $0.05(*)$ or $0.01\left(^{* *}\right)$.

maintained them longer throughout the day, remained higher at night, and kept air temperatures at plant height above $0{ }^{\circ} \mathrm{C}$ during more cold nights.

The use of rowcovers had a more regular and consistent influence on GDH accumulation when compared with the uncovered control (Table 2). During F2010 and F2011, the use of plant covers significantly increased GDH accumulation compared with the open controls. The majority of that influence was due to the addition of covers because there was only the occasional significant difference between GDH accumulations when fabric rowcovers were compared with plastic covered low tunnels. Periodically, there were significant interactions between soil heating and plant cover treatments. While infrequent, most were due to slightly lower GDH values in low tunnel treatments which were either heated or not heated (data not shown).

During W2011 and W2012, there was only one occasion when soil heating and covers interacted and was significant $(P=$ 0.042; not shown). More importantly, plant covers had a more significant effect on accumulated GDH (Table 2) than did type of cover used. During W2011, plant covers significantly increased GDH compared with the uncovered control. However, there was no difference in GDH between the rowcovers and low tunnels. In W2012, early in the production cycle (day 1-30) when temperatures were low (Table 1), covers significantly increase GDH compared with the uncovered control. Later in the production period (day 31-60), no difference in GDH was noted between covered and uncovered treatments. In both winter periods, GDH accumulation differences between rowcovers and low tunnels were not significant.

Plant growth responses to soil heating and plant covers. With variations in environmental conditions in fall (mid-October to late December) and winter (late January to late March), spinach yields and RGRs were unique for each production period. There was no significant interaction between soil heating and plant covers when fresh plant biomass was evaluated (Table 3 ). Soil heating only had a significant effect on spinach biomass (g/plant) in the F2010 (Table 3; two occasions) but had no effect during the other three trials.

On nearly all sampling dates, plant biomass was significantly greater for spinach grown under plant covers when compared with the uncovered controls regardless of planting date (different start times) or growing period (fall or winter) (Table 3). In F2010, by the end of the study, spinach biomass was $47 \%$ greater for plants grown under covers compared with the open controls. Fewer growth differences between the open controls and covered plants were noted when spinach was planted earlier in the year as in F2011. During W2011 and W2012 (Table 3), spinach biomass was always greater for plants grown under covers compared with plant grown without covers except at the last harvest in each study.

Differences in spinach biomass accumulation between plants grown under rowcovers or low tunnels were statistically distinguishable using orthogonal contrasts (Table 3 ). In F2010 trial, when spinach was planted in early November, plants under low tunnels grew better and accumulated more biomass than plants grown under rowcovers (Table 3 ).
In contrast, when spinach was planted earlier in F2011, no difference in biomass was detected between the spinach grown under rowcovers or low tunnels. While we did not directly compare the productivity between years in our analysis, final harvest date biomass values were quite low when spinach was planted later in F2010 trial than the earlier planting date in F2011.

In W2011 trial, few differences in biomass accumulation were noted between the rowcover and low tunnel treatments during a time when air and soil temperatures were low (Table 3). However, as the W2011 season progressed and growing conditions improved, spinach grown under low tunnels produced more biomass than plants grown under rowcovers. In W2012, spinach biomass was always significantly greater for plants grown under low tunnels compared with rowcovers. Because the two winter planting dates were closer to each other, differences in final plant biomass were more similar but still reflect seasonal environmental differences.

Production periods (fall or winter) influenced spinach RGRs differently (Fig. 2A-D). In the F2010 and F2011 trials, RGR decreased curvilinearly as days after planting increased. This pattern was consistent for soil heating treatments (data not shown) and plant covers (Fig. 2A and B). RGRs were significantly higher for spinach grown under rowcovers or low tunnels early in the production cycle compared with the open control. However, as the trial progressed, differences in RGR between the cover treatments were not detected.

In winter, RGR varied considerably between the cover treatments (Fig. 2C and D). In W2011 when temperatures were lower, 
Table 3. Influence of soil heating (main effect) and rowcovers (subplots) on spinach fresh weight (g/plant) when grown during fall (2010 and 2011) and winter (2011 and 2012).

\begin{tabular}{|c|c|c|c|c|c|c|c|c|c|c|c|c|}
\hline & \multicolumn{6}{|c|}{ Fall 2010 harvest dates } & \multicolumn{6}{|c|}{ Winter 2011 harvest dates } \\
\hline & 10 Nov. & 20 Nov. & 30 Nov. & 10 Dec. & 20 Dec. & 30 Dec. & 29 Jan. & 8 Feb. & 18 Feb. & 28 Feb. & 10 Mar. & 20 Mar. \\
\hline & \multicolumn{6}{|c|}{ (g/plant) } & \multicolumn{6}{|c|}{ (g/plant) } \\
\hline No heat & 1.60 & 3.77 & 3.73 & 5.20 & 7.67 & 9.00 & 1.21 & 1.96 & 4.51 & 7.19 & 16.88 & 30.05 \\
\hline Soil heat & 1.83 & 3.04 & 3.49 & 7.00 & 8.29 & 9.85 & 1.05 & 1.68 & 4.26 & 9.25 & 20.43 & 33.20 \\
\hline Sign 0.05 & $*$ & NS & NS & $*$ & NS & NS & NS & NS & NS & NS & NS & NS \\
\hline Open control & 1.42 & 3.48 & 2.43 & 3.85 & 5.64 & 5.39 & 0.92 & 1.16 & 2.40 & 3.82 & 10.10 & 25.09 \\
\hline Row cover & 1.85 & 2.78 & 3.67 & 5.67 & 7.54 & 8.73 & 1.34 & 1.90 & 5.16 & 7.11 & 16.66 & 27.20 \\
\hline Low Tunnel & 1.87 & 3.96 & 4.73 & 8.78 & 10.76 & 14.16 & 1.12 & 2.40 & 5.59 & 13.74 & 29.19 & 42.59 \\
\hline Covers & $* *$ & NS & $* *$ & $* *$ & $* *$ & $* *$ & NS & $*$ & $*$ & $* *$ & $* *$ & $*$ \\
\hline Open vs. Cover & $* *$ & NS & $* *$ & $* *$ & $* *$ & $* *$ & $*$ & $*$ & $* *$ & $* *$ & $* *$ & NS \\
\hline Row vs. Low & NS & $*$ & $*$ & $* *$ & $* *$ & $* *$ & NS & NS & NS & $* *$ & $* *$ & $*$ \\
\hline \multirow[t]{4}{*}{ Heat $\times$ Covers } & NS & NS & NS & NS & NS & NS & NS & NS & NS & NS & NS & NS \\
\hline & \multicolumn{6}{|c|}{ Fall 2011 harvest dates } & \multicolumn{6}{|c|}{ Winter 2012 harvest dates } \\
\hline & 21 Oct. & 31 Oct. & 10 Nov. & 20 Nov. & 30 Nov. & 10 Dec. & 6 Feb. & 16 Feb. & 26 Feb. & 7 Mar. & 17 Mar. & 27 Mar. \\
\hline & \multicolumn{6}{|c|}{ (g/plant) } & \multicolumn{6}{|c|}{ (g/plant) } \\
\hline No heat & 4.04 & 11.80 & 19.81 & 25.07 & 29.68 & 34.63 & 1.72 & 3.55 & 7.79 & 15.49 & 32.01 & 48.27 \\
\hline \multirow[t]{2}{*}{ Soil heat } & 3.54 & 11.68 & 22.54 & 28.22 & 34.50 & 37.64 & 2.19 & 3.40 & 7.20 & 15.74 & 32.47 & 55.77 \\
\hline & $*$ & NS & NS & NS & NS & NS & NS & NS & NS & NS & NS & NS \\
\hline Open control & 2.68 & 7.89 & 19.81 & 22.25 & 28.76 & 33.21 & 1.34 & 2.77 & 3.71 & 8.78 & 26.75 & 42.06 \\
\hline Row cover & 4.22 & 13.16 & 22.37 & 27.66 & 33.02 & 36.70 & 1.69 & 3.33 & 6.80 & 15.35 & 24.46 & 45.35 \\
\hline Low tunnel & 4.48 & 14.18 & 21.35 & 30.02 & 34.49 & 38.50 & 2.14 & 4.59 & 13.05 & 22.12 & 43.44 & 60.95 \\
\hline Covers & $* *$ & $* *$ & NS & $*$ & NS & NS & $* *$ & $*$ & $* *$ & $* *$ & $* *$ & $*$ \\
\hline Open vs. Cover & $* *$ & $* *$ & NS & $*$ & NS & NS & $*$ & $*$ & $* *$ & $* *$ & * & $*$ \\
\hline Row vs. Low & NS & NS & NS & NS & NS & NS & $*$ & $*$ & $* *$ & $* *$ & $* *$ & $*$ \\
\hline Heat $\times$ Covers & NS & NS & NS & NS & NS & NS & NS & NS & NS & NS & NS & NS \\
\hline
\end{tabular}

Not significant (NS) or significant at $0.05\left(^{*}\right)$ or $0.01\left({ }^{* *}\right)$.

spinach RGR for the uncovered control was significantly less than that of spinach grown under rowcovers at the first three harvests and significantly lower than RGR under low tunnels for the first four harvests. By day 50, however, there was no difference in RGR between cover treatments. Because RGR was increasing in the uncovered control as days after planting increased, by the final harvest, RGR in the uncovered control was significantly higher than the low tunnel treatment but not the rowcover treatment. The average RGR of spinach grown under rowcovers did not change during W2011 and averaged $63.0 \mathrm{mg} \mathrm{FW} / \mathrm{g} / \mathrm{d}$. In contrast, RGR of spinach grown under low tunnels increased through the first $40 \mathrm{~d}$ and then decreased rapidly late in the study.

In W2012 trial (Fig. 2D), spinach RGR in the open control remained constant throughout the study at $63.0 \mathrm{mg} \mathrm{FW} / \mathrm{g} / \mathrm{d}$. In contrast, RGR of spinach growing under rowcovers or low tunnels decreased linearly over time from a high of $106.0 \mathrm{mg} \mathrm{FW} / \mathrm{g} / \mathrm{d}$ to a low of $53.0 \mathrm{mg} \mathrm{FW} / \mathrm{g} / \mathrm{d}$ by the end of the study. Significant treatment differences in RGR were noted both early and late in W2012, but not during the middle $20 \mathrm{~d}$ of the study.

\section{Discussion}

The use of heating cables significantly increased soil temperature in all trials but had its greatest effect when temperatures were lowest late in the Fall and early in the Winter. Others have also reported that heating cables increase soil temperature (Bumgarner et al., 2011, 2012; Hunter, 2010; Rykbost et al., 1975). Heating cables allowed spinach roots to be exposed to soil temperatures within 7 to
$23{ }^{\circ} \mathrm{C}$ range which are optimal for spinach root growth. In contrast, plants grown without soil heating cables were sometimes flaccid in the early morning hours when soil temperatures were below the low temperature threshold of $7^{\circ} \mathrm{C}$.

The effectiveness of soil heating on winter spinach biomass production is dependent on external environmental conditions. During the fall when daylength shortens, most growth occurs early in the production cycle when plants are exposed to high air and soil temperatures and more solar radiation. Conversely, during winter, more growth occurs late in the production cycle when daylength increases, light levels improve, and average air and soil temperatures increase. In F2011, W2011, and W2012 trials, soil temperatures were higher than in the late planting of F2010. Better environmental conditions reduced the effectiveness of the soil heating cables, resulting in no difference in spinach productivity between unheated and heat soils (Table 3). While small increases in spinach productivity with heating cables were noted, differences were not as large as increased reported for other crops such as tomatoes, lettuce, or strawberry (Bumgarner et al., 2011; Hunter, 2010; Maughan et al., 2015; Rykbost et al., 1975). Cable position relative to the plants may play a role in this. Both Bumgarner et al. $(2011,2012)$ and Hunter (2010) positioned heating cables directly under lettuce plants which improved the growth response. In this study, cables were positioned between the planted rows $7-8 \mathrm{~cm}$ from the sensors which contributed to the lack of response to soil heating. Heating cable position should be considered when evaluating supplemental soil heating.
Secondary covers play a more important role in plant growth by protecting plants from extremely cold conditions while increasing the time plants experienced more optimal growing temperatures. During most of the 10-d measurement periods, spinach growing under plant covers were exposed to one to three more GDHs per day than the uncovered control (Table 2), and this directly contributed to improved spinach growth (Table 3). In a planting date study, Knewtson (2008) showed that planting earlier shortened the harvest interval whereas increasing the number of harvests and improving overall productivity. Much of the yield increases with earlier fall planting would be due to improvements in light and temperatures conditions. For a majority of leafy greens, including spinach, plants had good vigor and showed promise for HT winter production (Borrelli et al., 2013). They reported spinach produced yields of 30-50 g per plant in 10-11 weeks. Except for the late F2010 planting date, spinach yields in this study were at or above 30 g per plant after 8 weeks' growth, and were of high quality and vigor. While we did not look specifically at optimal planting date, selection of a mid-late October planting date ensures adequate temperatures and light levels for good growth in the fall. Planting later like in F2010, exposed plants to lower temperatures and light conditions which reduced plant productivity. Planting again in late January resulted in timing production to use the improving environmental conditions of late winter.

Most studies conducted in HT collect environmental data (Borrelli et al., 2013; Wallace et al., 2012) that are used to calculate growing degree day (GDD) information. 

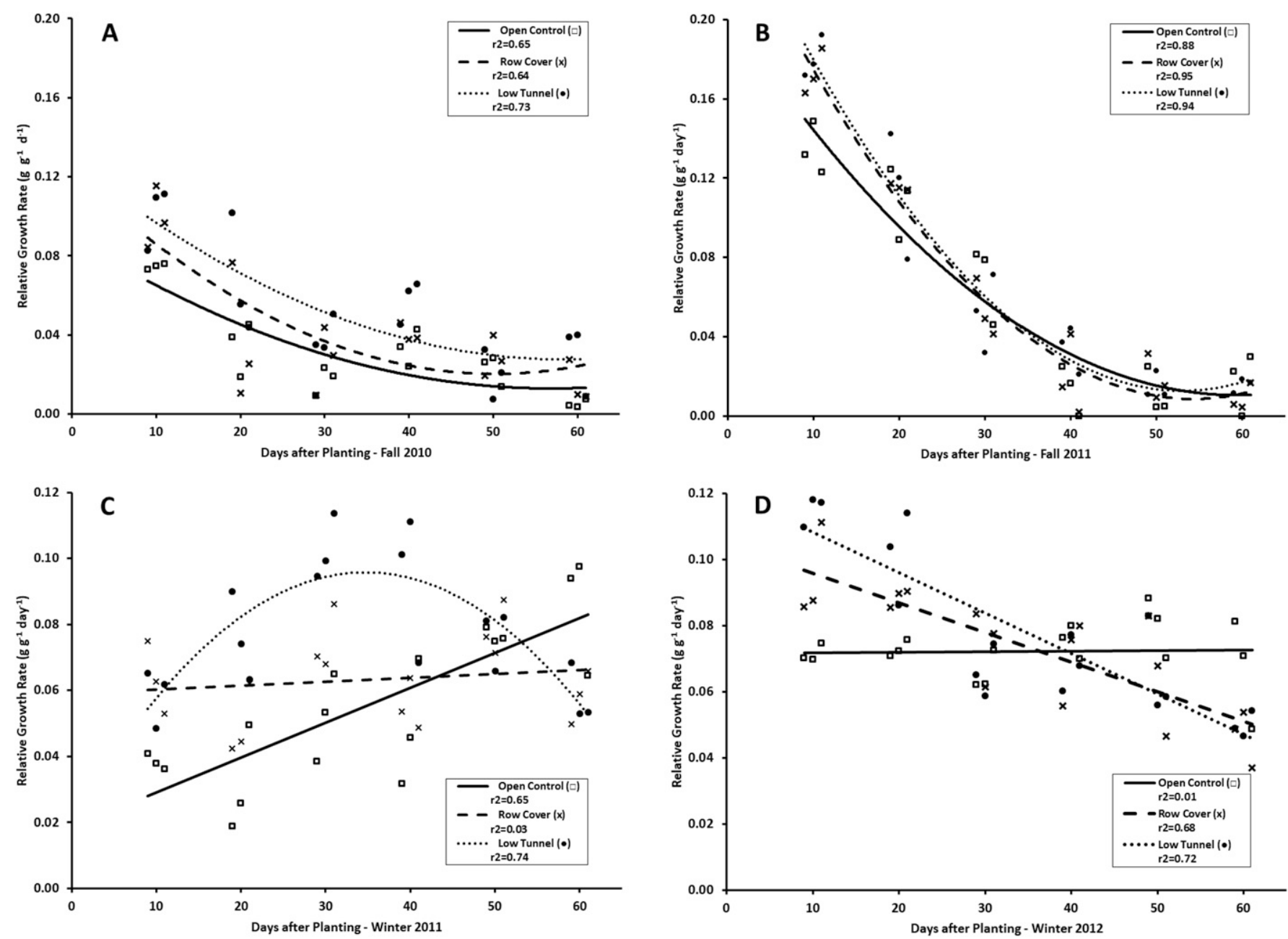

Fig. 2. Relative growth rates (g. $\mathrm{g}^{-1} \cdot \mathrm{d}^{-1}$ ) for Fall 2010 and 2011 (Panels A and B) and Winter 2011 and 2012 (Panels C and D) high tunnel spinach. Spinach were grown uncovered in an open control $(\square)$, under floating rowcovers $(-)$, or plastic covered low tunnels $(\cdots)$. Growth rates calculated from average fresh weight of leaves according to Hoffmann and Poorter (2002).

These data should be expressed as GDH because GDH provides a measure of the number of hours each day temperatures are adequate for plant growth. $\mathrm{Gu}(2016)$ pointed out the weakness of using GDD and the systematic inaccuracies that arise particularly when temperature conditions are near the minimum for the crop of interest. Because GDD calculates values using one temperature for $1 \mathrm{~d}$, GDD lacks precision, cannot separate data for a meaningful range of temperatures, and does not distinguish for time periods shorter than $1 \mathrm{~d}$ (day or night) that may be of interest. The largest errors in GDD occurred early or late in the year when daily low temperatures are below the base temperature used in the GDD equation $(\mathrm{Gu}$, 2016). Results from this study clearly demonstrate that in late fall or early winter, a significant number of GDHs accumulate each day when soil heating or plant covers were used, and this contributed to improvements in spinach growth.

Even though accumulated GDH were not different between the rowcover and low tunnels on most dates in fall or winter (Table 2), spinach growth was significantly improved by covering plants compared with no covers (Table 3; Fig. 2). Glenn (1984) and Glenn et al. (1984) noted that for autumngrown greenhouse lettuce and spinach, growth seemed more responsive to radiation levels than to temperature. Spinach RGR for the fall production periods in our study show a steady decrease in growth that is reflective of both the decrease in light and temperature occurring as fall progresses toward winter. It is unclear if temperature or light is more critical because both are near the minimum for adequate growth.

Conversely, in winter, plants seem more responsive to temperature because radiation levels are rapidly increasing. A field study with fall-planted lettuce or spinach grown under floating rowcovers supports this (Gimenez et al., 2002) as does a greenhouse study with fall, winter, and spring lettuce (Glenn, 1984). Gimenez et al. (2002) showed that light levels under rowcovers were often insufficient to provide for higher growth even though temperature conditions were more favorable under the rowcovers. Borrelli et al. (2013) suggests that consistently higher day and night temperatures may be more critical for higher yields than where environmental conditions provide for higher light intensities but have more widely fluctuating temperatures. The higher RGR at the start of the winter production periods in this study illustrates the benefits of higher temperature on growth. However, by the end of the winter production cycle, temperatures may actually be too high under rowcovers and low tunnels. The lower RGR under plant covers at 50 and $60 \mathrm{~d}$ after planting in winter were lower than the open control suggesting environmental conditions were no longer optimal.

\section{Conclusions}

Soil heating significantly raised soil temperatures and occasionally increased GDH when compared with the unheated control, but it did not improve spinach growth in either fall or winter production periods. These findings suggest there is little benefit from adding supplemental heat even when the production period is cold. While these findings differ from those reported for other crops (Bumgarner et al., 2011; Hunter et al., 2012; Rykbost et al., 1975), heating cable position and temperature set points may have contributed to the lack of a response. In addition, spinach is very cold tolerant which 
may further explain the lack of response to supplemental soil heat.

Day and night air and soil temperatures were significantly higher under covers when compared with uncovered controls. Air and soil temperatures beneath secondary covers increased faster in the morning, reached a higher temperature for a longer time during the day, decrease more slowly in the evening, and remain higher during the night. This allowed the spinach grown beneath secondary covers to accumulate more GDH which lead to increased growth (higher RGR) and higher final plant fresh weight during the fall and winter production periods. While there were no differences in GDH between spinach growing under rowcovers or low tunnels, on most sampling dates and at the end of the studies, spinach grown under low tunnels yielded more than when grown under rowcovers. This suggests that in the colder low light conditions of fall and winter, light levels may be more limiting than temperature for the plant growth response of cold hardy cool season HT crops like spinach.

\section{Literature Cited}

Anderson, J.L., E.A. Richardson, and C.D. Kesner 1986. Validation of chill unit and flower bud phenology models for 'Montmorency' sour cherry. Acta Hort. 184:71-78.

Black, B., J. Frisby, K. Lewers, F. Takeda, and C. Finn. 2008. Heat unit model for predicting bloom dates in Rubus. HortScience 43:20002004.

Borrelli, K., R.T. Koenig, B.M. Jaeckel, and C.A. Miles. 2013. Yield of leafy greens in high tunnel winter production in the Northwest United States. HortScience 48:183-188.

Boswell, V.R. 1934. A study of the temperature, day length, and development interrelationships of spinach varieties in the field. Proc. Amer. Soc. Hort. Sci. 32:549-557.

Bumgarner, N.R., M.A. Bennett, P.P. Ling, R.W. Mullen, and M.D. Kleinhenz. 2011. Canopy cover and root-zone heating effects on fall and spring grown leaf lettuce yields in Ohio. HortTechnology 21:737-744.

Bumgarner, N.R., J.C. Scheerens, R.W. Mullen, M.A. Bennett, P.P. Ling, and M.D. Kleinhenz.
2012. Root-zone temperature and nitrogen affect the yield and secondary metabolite concentration of fall- and spring-grown, high-density leaf lettuce. J. Sci. Food Agr. 92:116-124.

Fennell, A. and P.H. Li. 1987. Freezing tolerance and rapid cold acclimation of spinach. J. Amer. Soc. Hort. Sci. 112:306-309.

Gimenez, C., R.F. Otto, and N. Castilla. 2002. Productivity of leaf and root vegetables under direct covers. Sci. Hort. 94:1-11.

Glenn, E.P. 1984. Seasonal effects of radiation and temperature on growth of greenhouse lettuce in a high insolation desert environment. Sci. Hort. 22:9-21.

Glenn, E.P., P. Cardran, and T.L. Thompson. 1984 Seasonal effects of shading on growth of greenhouse lettuce and spinach. Sci. Hort 22:231-239

$\mathrm{Gu}$, S. 2016. Growing degree hours - A simple, accurate, and precise protocol to approximate growing heat summation for grapevines. Intl. J. Biometeorol. 60:1123-1134.

Hoffmann, W.A. and H. Poorter. 2002. Avoiding bias in calculations of relative growth rate. Ann. Bot. 90:37-42.

Hunter, B.L. 2010. Enhancing out-of-season production of tomatoes and lettuce using high tunnels. MS Thesis, Utah State Univ., Logan.

Hunter, B., D. Drost, B. Black, and R. Ward. 2012. Improving growth and productivity of earlyseason high-tunnel tomatoes with targeted temperature additions. HortScience 47:733-740.

Iwama, S., N. Hamashima, M. Motai, and S. Kajita. 1954. Ecological studies on vegetables in regions of different altitudes: Spinach summer crops with special reference to their premature bolting. J. Hort. Ass. Japan 22:217-222.

Koike, S.T., M. Cahn, M. Cantwell, S. Fennimore, M. LeStrange, E. Natwick, R.F. Smith, and E. Takele. 2011. Spinach production in California. UCNAR Publ. 7212.

Knewtson, S.J.B. 2008. Fall spinach-harvest date and yield in high tunnels. Kansas State University, 25 Apr. 2017. <http://www.hightunnels. org/ForGrowers/CoolSeasonVegetables/ SpinachHarvestDate.htm $>$.

Lamont, W.J., Jr. 2009. Overview of the use of high tunnels worldwide. HortTechnology 19:25-29.

Leone, A., C. Perrotta, and B. Maresca. 2003. Plant tolerance to heat stress: Current strategies and new emergent insights, p. 1-22. In: L.S. di Toppi and B. Pawlik-Skowrońska (eds.). Abiotic stress in plants. Kluwer Academic Publishers, Dordrecht, The Netherlands.

Marques, R. 2016. Pre-harvest effects on the quality of babyleaf spinach. Horticulture Innovation Australia Limited. 3 July 2017. $<$ http://ahr.com.au/wp-content/uploads/2016/ 12/ICP_PreHarvestBabyleaf_web.pdf $>$.

Maughan, T.L., K.R. Curtis, B.L. Black, and D.T. Drost. 2015. Economic evaluation of implementing strawberry season extension production technologies in the U.S. Intermountain West. HortScience 50:395-401.

Maynard, D.N. and G.J. Hochmuth. 2007. Knott's handbook for vegetable growers, 5 th ed. Wiley, Hoboken, NJ.

Rader, H.B. and M.G. Karlsson. 2006. Northern field production of leaf and romaine lettuce using a high tunnel. HortTechnology 16:649654.

Rowley, D., B. Black, D. Drost, and D. Feuz. 2010. Early-season extension using June-bearing 'Chandler' strawberry in high-elevation high tunnels. HortScience 45:1464-1469.

Rykbost, K.A., L. Boersma, H.J. Mack, and W.E. Schmisseur. 1975. Yield response to soil warming: Vegetable crops. Agron. J. 67:738-743.

Ruelland, E., M.N. Vaultier, A. Zachowski, and V. Hurry. 2009. Cold signaling and cold acclimation in plants. Adv. Bot. Res. 49:35-150.

Schöner, S. and G.H. Krause. 1990. Protective systems against active oxygen species in spinach: Response to cold acclimation in excess light. Planta 180:383-389.

Wallace, R.W., A.L. Wszelaki, C.A. Miles, J.S. Cowan, J. Martin, J. Roozen, B. Gundersen, and D.A. Inglis. 2012. Lettuce yield and quality when grown in high tunnel and open-field production systems under three diverse climates. HortTechnology 22:659-668.

Wien, H.C., J.E. Reid, C. Rasmussen, and M.D. Orzolek. 2006. Use of low tunnels to improve plant growth in high tunnels. 25 Apr. 2017. $<$ http://www.hort.cornell.edu/wien/cutflowers/ reports/20081ow_tunnel_temp.pdf $>$.

Waterer, D. 2003. Yield and economics of high tunnels for production of warm season vegetable crops. HortTechnology 13:339-343.

Wells, O.S. and J.B. Loy. 1985. Intensive vegetable production with row covers. HortScience 20:822-826. 